\title{
Does Corporate Diversification Increase Shareholder Value? The Case of Taiwan
}

\author{
Ilia Tetin \\ I-Shou University \\ Elizaveta Antonenko \\ South Ural State University
}

\begin{abstract}
We consider the effect of reinvestment on shareholder value to answer whether diversification decreases or increases shareholder value. We build static panel regression models for the sample of 1189 Taiwanese firms for 2009-2019. We also account for dynamic features associated with shareholder value and utilize Generalized Method of Moments estimates for a dynamic panel. There is robust evidence that reinvestment activity adds shareholder value. We also argue that current reinvestment activity leads to higher values of the closing price. Analysis reveals that the interaction effect of the normalized value of cash outflow and firm size leads to higher excess returns.
\end{abstract}

Keywords: reinvestment activity, diversification, shareholder value, GMM

\section{INTRODUCTION}

Corporations can use two pure diversification strategies: (1) internal diversification, relying on the development of products or services, or (2) external diversification, relying on the acquisition of other firms (Lamont and Anderson, 1985). Whereas internal development projects often require long periods before yielding positive returns (Biggadike, 1979; Burgelman, 1983; Fast, 1978), acquisitions will, in most cases, instantaneously increase the acquiring firm's revenues. Much of the external acquisition activity was strategic as firms merged and acquired firms from different industries in an effort to position themselves for entry into new and emerging markets. Thus, an age-old question from the archives of financial economics has been revived: Does corporate diversification create or destroy shareholder value? One school of literature indicates that diversification cannot produce value increases, and shareholders can achieve diversification by themselves (Brealey et al., 2000). On the opposing view, the downward risk resulting from diversification at the firm level serves to increase the diversified firm's debt capacity. To the extent that debt capacity adds value, diversification can be a source of added value (Lewellen, 1971). Finally, corporate diversification may create shareholder value by mitigating failures in the product, labour, and financial markets. This could be particularly important in emerging and less developed markets (Khanna and Palepu, 1999; Martin and Sayrak, 2003) 


\section{LITERATURE REVIEW}

Morck et al. studied three types of acquisitions between 1975 and 1987 that resulted in negative returns to bidding firms (Morck et al., 1990), stating that managerial decisions may drive acquisitions that reduce bidding firms' values. Several pioneer studies showed that market values diversified firms lower than standalone firms (Berger and Ofek, 1995; Larry H. P. Lang and Stulz, 1994; Servaes, 1996). This fact is known as a "diversification discount." Diversification may cause discount due to information loss (Ozbas, 2005) or due to agency problem that brings misguided investments (McNeil and Smythe, 2009) or due to market efficiency (Aggarwal and Zhao, 2009).

The evidence suggests that, for the average firm operating in developed capital markets, the costs of diversification outweigh the benefits. In the study of East Asian countries (including Taiwan), Claessens stated that diversification impacts negatively on a firm value (Claessens et al., 2000). Hyland (Hyland and Diltz, 2002) found that diversifying firms have slightly worse financial performance than their specialized counterparts, but in later work, they did not find evidence of a long-term reduction in firm value associated with diversification (Hyland, 2003). Matsusaka presented evidence that diversifying acquisitions were beneficial to bidding firms (Matsusaka, 1993). Positive returns to diversification announcements were registered by Hubbard and Palia (Hubbard and Palia, 1999).

Following the abovementioned studies, one can find that responses to diversification announcements tend to vary over time. These responses allow the highest returns in the 1960s and 1970s and the lowest in the 1970s and 1980s. Akbulut and Matsusaka provide evidence: diversifying mergers earned higher announcement returns in periods when external capital was relatively scarce (Akbulut and Matsusaka, 2010). More recent papers show that results on diversification might create value, but in order to measure it, one has to provide corrections for endogeneity. For instance, Hoechle (Hoechle et al., 2012) investigated that corporate governance narrows the discount to the extent that it disappears entirely. In emerging markets of Chile, Jara-Bertin reports that the ownership diversification discount becomes a premium when the ownership diversification enables the control of the affiliated firms, which happens due to improvements of internal capital markets (Jara-Bertin et al., 2015). Chang et al. studied the effect of diversification during the financial crisis of 2008-2009 and stated that diversification is profitable after the correction of selection bias (Chang et al., 2016). Setianto, in his study of the Indonesian market, revealed the U-shaped curve between diversification and growth opportunities, allowing the gain of diversification premium with optimal choices of managers (Setianto, 2020).

Debate in the finance literature whether or not corporate diversification is a value maximization strategy for shareholders continues, and in this paper, we will focus on a question, whether diversification destroys or creates value in the Taiwan market.

\section{METHODS}

\section{Data}

This study uses Taiwan Economic Journal (TEJ) database. TEJ provides a standardized and uniform format of financial information for Chinese and Taiwanese firms. We collected data for the period of 20092019. We excluded firms whose primary business is financial services (SIC 6000-6999). Initially, we selected 1564 public firms. After that, we excluded records with incomplete and missing information. In the end, we formed a balanced panel which consists of 13079 firm-years with 1189 unique firms.

Our primary variable of interest is the normalized value of cash outflow $C A$, which is calculated as a sum of newly invested capital and net cash paid for purchasing and merging other companies. $C A$ values are normalized by dividing them on assets. We use excessive return as a proxy for shareholder value $(Y)$, calculated as the difference between the rate of return and market return. We also check the relationship between closing price (Price) and $C A$. 


\section{Empirical Model}

We used panel data methodology for our study to address common econometric problems. Endogeneity: which appears when the error term is correlated with independent variables. This correlation violates ordinary least squares (OLS) estimation assumptions, which require explanatory variables to be strictly exogenous and, consequently, uncorrelated with the error term. Unobservable heterogeneity: we account for the individual firm-specific effect, which causes some firms to be more or less willing to perform diversification and, as a result, affects the shareholder value. We control this unobservable heterogeneity in firms to avoid biased results by modelling it as individual effects. Consequently, the error term in our models contains individual effects, time dummies, and a random component.

To investigate the association of reinvestment activity with the closing price, we estimate the following model:

Price $_{i t}=\beta_{1} C A_{i, t}+\beta_{2} C A_{i, t-1}+\beta_{3} C A_{i, t-2}+\beta_{4} F S_{i, t-1}+\beta_{5} P B_{i, t-1}+\beta_{6} D H_{i, t-1}+\beta_{6} E P S_{i, t}+$ $\beta_{7} E P S_{i, t-1}+\beta_{8} R O I_{i, t-1}+\beta_{9} R O I_{i, t-2}+\varepsilon_{i t}$

where $i$ - is an individual firm, $t$ - is a time period, $F S$ - firm size (calculated as log of total assets squared), $P B$ - Price-to-book ratio, $D H$ - Director holdings (\%), EPS - Current earnings per share, ROI - Return on investment.

To investigate the association of reinvestment activity with shareholder value, we estimate the following model:

$Y_{i t}=\beta_{1} C A_{i, t}+\beta_{2} C A_{i, t-1}+\beta_{3} C A_{i, t-2}+\beta_{4} F S_{i, t}+\beta_{5} F S_{i, t-1}+\beta_{6}\left(F S_{i, t} * C A_{i, t}\right)+\beta_{7} P B_{i, t}+$

$\beta_{8} D H_{i, t-1}+\beta_{9} E P S_{i, t}+\beta_{10} A T_{i, t}+\beta_{11} R O I_{i, t-1}+\beta_{12} R O I_{i, t-2}+u_{i t}$

where $F S_{i, t} * C A_{i, t}$ - is an interaction term between Firm size and the normalized value of cash outflow, $A T$ - asset turnover ratio.

To gain more insights into the actual effect of $C A$, we estimate two dynamic panel models by including a lagged dependent variable on the right side of the equation:

$Y_{i t}=v_{1} Y_{i, t-1}+v_{2} C A_{i, t-1}+v_{3}$ Price $_{i, t-1}+\epsilon_{i t}$

and

$Y_{i t}=\varphi_{1} Y_{i, t-1}+\varphi_{2}\left(F S_{i, t-1} * C A_{i, t-1}\right)+\varphi_{3}$ Price $_{i, t-1}+\theta_{i t}$

This inclusion of lagged independent variables makes static panel model estimators biased and inconsistent (Baltagi, 2013; Nickell, 1981). To overcome these problems (Arellano and Bond, 1991) proposed a generalized method of moments (GMM) estimator. The basic idea is to take the first difference to eliminate individual effects and use the lagged values of the right-hand side variables included in the model as instruments. A potential problem with the difference GMM estimator is that lagged independent variables can be weak instruments due to the persistence of the autoregressive process or a smaller variance of idiosyncratic error compared to the variance of panel effects. We used two-step GMM as it proved to be more asymptotically efficient (Baltagi, 2021, 2013). The consistency of the GMM estimator depends on the validity of the moment conditions and the lack of second-order correlation. The Sargan-Hansen test with $H_{0}$ : instruments are exogenous as a group, used to check the lack of correlation between the instruments and the idiosyncratic error term (Hansen, 1982; Sargan, 1958). First-order serial correlation naturally presents in the GMM estimator, but second-order correlation needs to be checked by AR2 test with $H_{0}$ : there is no second order serial correlation, derived by Arellano and Bond (Arellano and Bond, 1991). We also performed two Wald tests: (1) on significance of the reported coefficients and (2) on joint significance of the time dummies. 


\section{RESULTS}

Table 1 contains descriptive statistics and univariate results for our sample. The mean $Y$ is 0.159 . On average, firms without reinvestment activity have a higher value of excess return 0.173 vs 0.145 . However, the results of the t-test of means allow us to state there is no significant difference in means $(p>0.05)$. Note negative values of $C A$, which will influence the interpretation of regression estimates. Firm size is slightly higher for firms with reinvestment activity 31.194, though this difference in means is not statistically significant. Also, the asset turnover ratio $(A T)$ is about the same, $0.712 \mathrm{vs} 0.718$. This means that selected firms have comparable characteristics. Director holdings $(D H)$ show significantly $(\mathrm{p}<0.01)$ lower values for firms with reinvestment activity. Earnings per share (EPS) has a much higher value of 1.976 compared to only 1.461 for firms without reinvestment activity. The same statement is valid for the Price variable, which is significantly $(p<0.01)$ higher.

TABLE 1

DESCRIPTIVE STATISTICS

\begin{tabular}{|l|c|c|c|c|c|c|c|}
\hline \multicolumn{4}{|c|}{ Whole sample (N=13079) } & $\begin{array}{c}\text { With } \\
\text { reinvestment } \\
\text { activity } \\
\text { (N=6386) }\end{array}$ & $\begin{array}{c}\text { Without } \\
\text { reinvestment } \\
\text { activity } \\
(\mathrm{N}=6693)\end{array}$ & Difference \\
\hline Variable & Mean & Std. Dev. & 25 pct & 75 pct & Mean & Mean & $\Delta$ Mean \\
\hline$Y$ & 0.159 & 0.897 & -0.191 & 0.236 & 0.145 & 0.173 & -0.029 \\
\hline$C A$ & -0.018 & 0.046 & -0.016 & 0 & -0.036 & 0 & -0.036 \\
\hline$F S$ & 30.470 & 2.827 & 28.564 & 32.055 & 31.194 & 29.779 & 1.415 \\
\hline$P B$ & 1.682 & 2.878 & 0.902 & 1.934 & 1.644 & 1.718 & -0.075 \\
\hline$D H$ & 22.391 & 14.417 & 11.900 & 29.310 & 20.286 & 24.399 & -4.113 \\
\hline$E P S$ & 1.713 & 5.259 & -0.015 & 2.580 & 1.976 & 1.461 & 0.515 \\
\hline AT & 0.715 & 0.589 & 0.350 & 0.909 & 0.712 & 0.718 & -0.006 \\
\hline ROI & 0.274 & 0.983 & -0.140 & 0.363 & 0.26 & 0.286 & -0.026 \\
\hline Price & 36.617 & 90.468 & 12.500 & 38.400 & 40.020 & 33.369 & 6.651 \\
\hline
\end{tabular}

Table 2 presents the Spearman correlations between the variables in our models.

TABLE 2

CORRELATION MATRIX

\begin{tabular}{|l|c|c|c|c|c|c|c|c|c|}
\hline & $D H$ & $P B$ & $Y$ & $R O I$ & $F S$ & $E P S$ & Price & $C A$ & $A T$ \\
\hline$D H$ & 1 & & & & & & & & \\
\hline$P B$ & 0.029 & 1 & & & & & & & \\
\hline$Y$ & 0.021 & 0.140 & 1 & & & & & & \\
\hline ROI & 0.025 & 0.140 & $0.970^{* * *}$ & 1 & & & & & \\
\hline FS & -0.160 & -0.080 & -0.056 & -0.060 & 1 & & & & \\
\hline EPS & -0.009 & 0.120 & 0.065 & 0.054 & 0.250 & 1 & & & \\
\hline Price & -0.003 & 0.180 & 0.074 & 0.073 & 0.170 & $0.890^{* * *}$ & 1 & & \\
\hline CA & 0.016 & -0.031 & -0.035 & -0.034 & 0.042 & 0.022 & -0.007 & 1 & \\
\hline AT & 0.059 & 0.055 & 0.053 & 0.051 & -0.018 & 0.080 & 0.039 & 0.062 & 1 \\
\hline
\end{tabular}

Notes: $* * *$ - denotes significance at the $1 \%$ 
We witness significant positive correlations between $Y$ and $R O I(0.97, p<0.01)$ and between Price and $E P S(0.89, p<0.01)$. Since both $Y$ and Price will be considered independent variables in building our models, multicollinearity is not an issue. Nearly functional dependence between $Y$ and $R O I$ makes us exclude $R O I$ from the model in favour of its lagged values. Correlations between $C A$ and $Y$, and between $C A$ and Price are both negative and insignificant $(p<0.01)$.

Table 3 presents fixed panel regressions of reinvestment activity on Price and shareholder value.

TABLE 3

STATIC PANEL ESTIMATES

\begin{tabular}{|c|c|c|c|c|c|}
\hline \multirow[t]{2}{*}{ Variables and tests } & \multicolumn{5}{|c|}{ Dependent variable } \\
\hline & $\begin{array}{l}\text { Price } \\
\text { (1) }\end{array}$ & $\begin{array}{c}\log (\text { Price }) \\
\text { (2) }\end{array}$ & $\begin{array}{c}Y \\
(3)\end{array}$ & $\begin{array}{c}Y \\
(4)\end{array}$ & $\begin{array}{c}Y \\
(5)\end{array}$ \\
\hline$C A$ & $\begin{array}{c}-12.509^{* *} \\
(5.828)\end{array}$ & $\begin{array}{c}-0.699 * * * \\
(0.057)\end{array}$ & $\begin{array}{c}-14.049 * * * \\
(6.166)\end{array}$ & $\begin{array}{c}-14.261^{* *} \\
(6.217)\end{array}$ & $\begin{array}{c}-14.437 * * \\
(6.082) \\
\end{array}$ \\
\hline Lagged $C A$ & $\begin{array}{c}-8.023 * * \\
(3.559)\end{array}$ & $\begin{array}{c}-0.231 * * \\
(0.091)\end{array}$ & $\begin{array}{c}0.028 \\
(0.294)\end{array}$ & $\begin{array}{c}-0.005 \\
(0.283)\end{array}$ & $\begin{array}{c}-0.018 \\
(0.282)\end{array}$ \\
\hline Lagged-2 $C A$ & $\begin{array}{c}1.884 \\
(6.544)\end{array}$ & $\begin{array}{c}0.013 \\
(0.124)\end{array}$ & $\begin{array}{c}0.521 * * * \\
(0.134)\end{array}$ & $\begin{array}{c}0.480 * * * \\
(0.139)\end{array}$ & $\begin{array}{c}0.503 * * * \\
(0.138)\end{array}$ \\
\hline$F S$ & - & - & $\begin{array}{c}0.303 * * * \\
(0.064)\end{array}$ & $\begin{array}{c}0.341 * * * \\
(0.068)\end{array}$ & $\begin{array}{c}0.321 * * * \\
(0.070)\end{array}$ \\
\hline Lagged $F S$ & $\begin{array}{c}1.021 \\
(1.282)\end{array}$ & $\begin{array}{c}0.150 * * * \\
(0.030)\end{array}$ & $\begin{array}{c}-0.520 * * * \\
(0.076)\end{array}$ & $\begin{array}{c}-0.546 * * * \\
(0.079)\end{array}$ & $\begin{array}{c}-0.505 * * * \\
(0.078)\end{array}$ \\
\hline$P B$ & - & - & $\begin{array}{c}0.033 * * \\
(0.014) \\
\end{array}$ & $\begin{array}{c}0.033 * * \\
(0.014)\end{array}$ & $\begin{array}{c}0.032 * * \\
(0.014)\end{array}$ \\
\hline Lagged $P B$ & $\begin{array}{c}0.440 * * * \\
(0.127)\end{array}$ & $\begin{array}{l}0.009 * \\
(0.005)\end{array}$ & - & - & - \\
\hline Lagged $D H$ & $\begin{array}{c}-0.150^{* *} \\
(0.076) \\
\end{array}$ & $\begin{array}{c}0.001^{*} \\
(0.001) \\
\end{array}$ & $\begin{array}{c}0.004 * * \\
(0.002)\end{array}$ & $\begin{array}{l}0.003^{*} \\
(0.002) \\
\end{array}$ & $\begin{array}{l}0.003^{*} \\
(0.002) \\
\end{array}$ \\
\hline$E P S$ & $\begin{array}{c}8.600 * * * \\
(1.608)\end{array}$ & $\begin{array}{c}0.044 * * * \\
(0.004)\end{array}$ & $\begin{array}{c}0.023 * * * \\
(0.006)\end{array}$ & $\begin{array}{c}0.021 * * * \\
(0.005)\end{array}$ & $\begin{array}{c}0.039 * * * \\
(0.007)\end{array}$ \\
\hline Lagged $E P S$ & $\begin{array}{c}5.820 * * * \\
(0.570)\end{array}$ & $\begin{array}{c}0.003 \\
(0.005)\end{array}$ & - & - & $\begin{array}{c}-0.029 * * * \\
(0.004)\end{array}$ \\
\hline$A T$ & - & - & - & $\begin{array}{c}0.267 * * * \\
(0.053)\end{array}$ & $\begin{array}{c}0.255^{* * *} \\
(0.048)\end{array}$ \\
\hline Lagged $R O I$ & $\begin{array}{c}-2.365^{* *} \\
(1.064)\end{array}$ & $\begin{array}{c}0.104 * * * \\
(0.019)\end{array}$ & $\begin{array}{c}-0.141 * * * \\
(0.036)\end{array}$ & $\begin{array}{c}-0.144 * * * \\
(0.036)\end{array}$ & $\begin{array}{c}-0.139 * * * \\
(0.035)\end{array}$ \\
\hline Lagged-2 ROI & $\begin{array}{c}-2.392 * * * \\
(0.582) \\
\end{array}$ & $\begin{array}{c}0.010 \\
(0.027) \\
\end{array}$ & $\begin{array}{c}-0.115^{* * *} \\
(0.027)\end{array}$ & $\begin{array}{c}-0.121 * * * \\
(0.026)\end{array}$ & $\begin{array}{c}-0.113^{* * * *} \\
(0.025) \\
\end{array}$ \\
\hline$C A * F S$ & - & - & $\begin{array}{c}0.473 * * \\
(0.204)\end{array}$ & $\begin{array}{c}0.480 * * \\
(0.205)\end{array}$ & $\begin{array}{c}0.485^{* *} \\
(0.201)\end{array}$ \\
\hline Adjusted $R^{2}$ & 0.555 & 0.133 & 0.028 & 0.036 & 0.046 \\
\hline Observations & 10701 & 10701 & 10701 & 10701 & 10701 \\
\hline Hausman test & 441.38 & 266.92 & 1646.9 & 1859.4 & 1510.4 \\
\hline Pesaran CD test & 134.70 & 367.22 & 31.32 & 34.69 & 29.939 \\
\hline Breusch-Pagan test & 602822 & 67049 & 24784 & 24971 & 25715 \\
\hline
\end{tabular}

Notes: (1) Standard errors are in round brackets, robust to heteroscedasticity and serial correlation. (2) *** - denotes significance at the $1 \% ;{ }^{* *}$ - at the $5 \%,{ }^{*}$ - at the $10 \%$ levels; (3) $C A * F S$ denotes the interaction between $C A$ and $F S$. 
We tested fixed-effects vs random-effects models with the Hausman test, which favours fixed effects in all comparisons $p<0.01$. The Pesaran CD test for cross-sectional dependence in panels and the BreuschPagan test shows cross-sectional dependence and heteroscedasticity. We control these issues by providing standard errors, robust to heteroscedasticity and serial correlation.

In the first model, where the dependent variable is Price, both the coefficient of $C A$ and the one-period lag coefficient of $C A$ are negative and significant at the $5 \%$ level. The two-period lagged values of $C A$ are positive and not significant. This fact allows us to state that reinvestment activity in the previous period and reinvestment activity in the current period positively impact Price values (due to negative values of $C A$ itself). This corresponds with statistics, where closing prices of firms performing reinvestments are $19.93 \%$ higher. Switching to logarithms in model (2) does not change the signs and significance of coefficients.

Table 3 contains three competitive models (3), (4), and (5). We consider model (5) as the final model due to higher adjusted $R^{2}$. We build models (3) and (4) to provide evidence on the responsiveness of $C A$ coefficients to the change of model's specification. The dependent variable is $Y$, and competitive models show an association between $C A$ and excessive returns. We find consistently positive and significant effects of $P B, A T, E P$, one-period lagged $D H$, on shareholder value. All models report a negative association $(\mathrm{p}<0.05)$ between current values of $C A$ and $Y$. All one-lagged $C A$ values appeared to be insignificant $(\mathrm{p}>0.1)$, and all two-period lagged values are statistically significant $(\mathrm{p}<0.01)$ with positive signs. Values of $C A$ and two-period lagged $C A$ are stable, meaning their low sensitivity to model specification changes.

It appears that reinvestments made in the previous year have no impact on the value of the excessive return. Analyzing coefficients of lagged variables, we might conclude that two-period lagged reinvestments harm, one-period lagged has ambiguous impact, and current reinvestments positively impact the shareholder value. Moreover, the value of this positive impact is much higher in terms of coefficient values.

It is worth noticing the significant interaction between the firm size $(F S)$ variable and the $C A$. The interaction is negative due to negative $\left(\beta_{1}+\beta_{6}\right)$ value. It shows that the effect of reinvestment activity is more significant for larger companies.

Table 4 presents dynamic panel estimates of two models.

\section{TABLE 4 \\ DYNAMIC PANEL ESTIMATES}

\begin{tabular}{|l|l|l|}
\hline Variables and tests & \multicolumn{1}{|c|}{$\begin{array}{c}\text { GMM-DIFF } \\
(1)\end{array}$} & \multicolumn{1}{c|}{$\begin{array}{c}\text { GMM-DIFF } \\
(2)\end{array}$} \\
\hline Lagged $Y$ & $0.0347^{* * *}(0.012)$ & $0.0348^{* * *}(0.007)$ \\
\hline Lagged $C A$ & $-0.944^{* *}(0.411)$ & - \\
\hline Lagged $C A * F S$ & - & $-0.032^{* *}(0.013)$ \\
\hline Lagged Price & $-0.018^{* * *}(0.005)$ & $-0.018^{* * *}(0.005)$ \\
\hline Observations & 10701 & 10701 \\
\hline Sargan /Hansen test & $8.308[0.404]$ & $8.326[0.402]$ \\
\hline Arellano-Bond test for AR (1) & $-3.460[0.001]$ & $-3.472[0.001]$ \\
\hline Arellano-Bond test for AR (2) & $0.438[0.661]$ & $0.435[0.663]$ \\
\hline Wald test for coefficients & $22.017[0.001]$ & $2.360[0.001]$ \\
\hline Wald test for time dummies & $96.534[0.001]$ & $95.953[0.001]$ \\
\hline
\end{tabular}

Notes: (1) The model is estimated with the two-step GMM. Robust standard errors are in parentheses. (2) For diagnostic tests, p-values are reported in squared brackets. (3) $C A * F S$ denotes the interaction between $C A$ and $F S$. (4) $* * *$ - denotes significance at the $1 \% ; * *$ - at the $5 \%$.

Diagnostic tests for both models show that selected instruments (higher lagged variables) as a group are exogenous $p>0.1$. There is no second-order autocorrelation $p>0.05$, and both coefficients and timedummies are jointly significant $p<0.01$. 
We estimate two dynamic panel models to study the actual effect of the normalized value of cash outflow on $Y$. Model (1) in Table 4 uses lagged $C A$, which, in the case of a dynamic model, represents the current effect of $C A$ on $Y$. This effect is negative and statistically significant $(p<0.05)$. This result confirms the fixed panel estimate of model (5) from Table 3, stating that the normalized value of cash outflow creates shareholder value.

Table 4 contains estimates of the model (2), where we are interested in the coefficient of the interaction term between $C A$ and Firm Size. The sign of the coefficient is negative, meaning that the effect of interaction is positive. This also confirms the results of fixed panel regression and states that the larger the firm size the more prominent will be excessive return with the same amount of normalized value of cash outflow.

\section{CONCLUSION}

In this paper, we examine whether and how corporate diversification relates to shareholder value. We undertake this study in Taiwan market environment on a relatively large sample of firms from different industries. We utilize static and dynamic panel regression models and obtain consistent results that reinvestment activity increases shareholder value. The findings of this study provide strong evidence that corporate diversification influence shareholder value with the increase in closing price. We argue that depending on the firm size, the effect of an increase in shareholder value is more significant, meaning that firms with a considerable value of assets are encouraged to implement a diversification strategy to gain a diversification premium.

\section{ACKNOWLEDGEMENT}

The authors would like to thank prof. Guan-Ru Chen for helpful comments.

\section{REFERENCES}

Aggarwal, R., \& Zhao, S. (2009). The Diversification Discount Puzzle: Evidence for a Transaction-Cost Resolution. Financ. Rev., 44, 113-135. https://doi.org/10.1111/j.1540-6288.2008.00212.x

Akbulut, M.E., \& Matsusaka, J.G. (2010). 50+ Years of Diversification Announcements. Financ. Rev., 45, 231-262. https://doi.org/10.1111/j.1540-6288.2010.00245.x

Arellano, M., \& Bond, S. (1991). Some Tests of Specification for Panel Data: Monte Carlo Evidence and an Application to Employment Equations. Rev. Econ. Stud., 58, 277. https://doi.org/10.2307/2297968

Baltagi, B.H. (2021). Econometric Analysis of Panel Data, Springer Texts in Business and Economics. Springer International Publishing, Cham. https://doi.org/10.1007/978-3-030-53953-5

Baltagi, B.H. (2013). Dynamic panel data models. In N. Hashimzade, \& M.A. Thornton (Eds.), Handbook of Research Methods and Applications in Empirical Macroeconomics, Chapters (pp. 229-248). Edward Elgar Publishing.

Berger, P.G., \& Ofek, E. (1995). Diversification's effect on firm value. J. Financ. Econ., 37, 39-65. https://doi.org/10.1016/0304-405X(94)00798-6

Biggadike, E.R. (1979). Corporate diversification: Entry, strategy, and performance. Division of Research, Graduate School of Business Administration, Harvard University, Boston.

Brealey, R.A., Myers, S.C., \& Krishnan, V.S. (2000). Study guide for use with "Principles of corporate finance (6th Ed.). Irwin/McGraw-Hill, Boston.

Burgelman, R.A. (1983). A Process Model of Internal Corporate Venturing in the Diversified Major Firm. Adm. Sci. Q., 28, 223. https://doi.org/10.2307/2392619

Chang, S., Kogut, B., \& Yang, J-S. (2016). Global diversification discount and its discontents: A bit of self-selection makes a world of difference: Global Diversification Discount and Its Discontents. Strateg. Manag. J., 37, 2254-2274. https://doi.org/10.1002/smj.2574 
Claessens, S., Djankov, S., \& Lang, L.H.P. (2000). The separation of ownership and control in East Asian Corporations. J. Financ. Econ., 58, 81-112. https://doi.org/10.1016/S0304-405X(00)00067-2

Fast, N.D. (1978). The rise and fall of corporate new venture divisions. Research for business decisions. UMI Research Press, Ann Arbor, Mich.

Hansen, L.P. (1982). Large Sample Properties of Generalized Method of Moments Estimators. Econometrica, 50, 1029. https://doi.org/10.2307/1912775

Hoechle, D., Schmid, M., Walter, I., \& Yermack, D. (2012). How much of the diversification discount can be explained by poor corporate governance? J. Financ. Econ., 103, 41-60. https://doi.org/10.1016/j.jfineco.2011.03.025

Hubbard, R.G., \& Palia, D. (1999). A Reexamination of the Conglomerate Merger Wave in the 1960s: An Internal Capital Markets View. J. Finance, 54, 1131-1152. https://doi.org/10.1111/00221082.00139

Hyland, D.C. (2003). The Effect of Diversification on Firm Value: A Pre- And Post- Diversification Analysis. Stud. Econ. Finance, 21, 22-39. https://doi.org/10.1108/eb028773

Jara-Bertin, M., López-Iturriaga, F.J., \& Espinosa, C. (2015). Diversification and control in emerging markets: The case of Chilean firms. BRQ Bus. Res. Q., 18, 259-274. https://doi.org/10.1016/j.brq.2015.01.002

Khanna, T., \& Palepu, K. (1999). Emerging Market Business Groups, Foreign Investors, and Corporate Governance (No. w6955). National Bureau of Economic Research, Cambridge, MA. https://doi.org/10.3386/w6955

Lamont, B.T., \& Anderson, C.R. (1985). Mode of Corporate Diversification and Economic Performance. Acad. Manage. J., 28, 926-934. https://doi.org/10.5465/256245

Lang, L.H.P., \& Stulz, R.M. (1994). Tobin's q, Corporate Diversification, and Firm Performance. J. Polit. Econ., 102, 1248-1280.

Lewellen, W.G. (1971). A Pure Financial Rationale for the Conglomerate Merger. J. Finance, 26, 521537. https://doi.org/10.1111/j.1540-6261.1971.tb00912.x

Martin, J.D., \& Sayrak, A. (2003). Corporate diversification and shareholder value: A survey of recent literature. J. Corp. Finance, 9, 37-57.

Matsusaka, J.G. (1993). Takeover Motives during the Conglomerate Merger Wave. RAND J. Econ., 24, 357. https://doi.org/10.2307/2555963

McNeil, C.R., \& Smythe, T.I. (2009). Division Manager Lobbying Power and the Allocation of Capital. Financ. Rev., 44, 59-85. https://doi.org/10.1111/j.1540-6288.2008.00210.x

Morck, R., Shleifer, A., \& Vishny, R.W. (1990). Do Managerial Objectives Drive Bad Acquisitions? J. Finance, 45, 31-48. https://doi.org/10.1111/j.1540-6261.1990.tb05079.x

Nickell, S. (1981). Biases in Dynamic Models with Fixed Effects. Econometrica, 49, 1417. https://doi.org/10.2307/1911408

Ozbas, O. (2005). Integration, organizational processes, and allocation of resources. J. Financ. Econ., 75, 201-242.

Sargan, J.D. (1958). The Estimation of Economic Relationships using Instrumental Variables. Econometrica, 26, 393. https://doi.org/10.2307/1907619

Servaes, H. (1996). The Value of Diversification During the Conglomerate Merger Wave. J. Finance, 51, 1201-1225. https://doi.org/10.1111/j.1540-6261.1996.tb04067.x

Setianto, R.H. (2020). Corporate diversification and firms' value in emerging economy: The role of growth opportunity. J. Asian Bus. Econ. Stud., 27, 195-207. https://doi.org/10.1108/JABES-082019-0075 